\title{
Mobile phones affect multiple sperm quality traits: a meta-
}

\section{analysis [version 1; peer review: 2 approved, 1 approved with}

\section{reservations]}

\author{
Madhukar Shivajirao Dama, M Narayana Bhat
}

Institute of Wildlife Veterinary Research, Kodagu District, Karnataka, India

\author{
V1 First published: 12 Feb 2013, 2:40 \\ https://doi.org/10.12688/f1000research.2-40.v1 \\ Latest published: 12 Feb 2013, 2:40 \\ https://doi.org/10.12688/f1000research.2-40.v1
}

\section{Abstract}

As mobile phone usage is growing rapidly, there is a need for a comprehensive analysis of the literature to inform scientific debates about the adverse effects of mobile phone radiation on sperm quality traits. Therefore, we conducted a meta-analysis of the eligible published research studies on human males of reproductive age. Eleven studies were eligible for this analysis. Based on the metaanalysis, mobile phone use was significantly associated with deterioration in semen quality (Hedges's $g=-0.547 ; 95 \% \mathrm{CI}:-0.713$, $0.382 ; p<0.001)$. The traits particularly affected adversely were sperm concentration, sperm morphology, sperm motility, proportion of nonprogressive motile sperm (\%), proportion of slow progressive motile sperm (\%), and sperm viability. Direct exposure of spermatozoa to mobile phone radiation with in vitro study designs also significantly deteriorated the sperm quality (Hedges's $g=-2.233 ; 95 \%$ CI: -2.758 , 1.708; $p<0.001)$, by reducing straight line velocity, fast progressive motility, Hypo-osmotic swelling (HOS) test score, major axis $(\mu \mathrm{m})$, minor axis $(\mu \mathrm{m})$, total sperm motility, perimeter $(\mu \mathrm{m})$, area $\left(\mu \mathrm{m}^{2}\right)$, average path velocity, curvilinear velocity, motile spermatozoa, and acrosome reacted spermatozoa (\%). The strength of evidence for the different outcomes varied from very low to very high. The analysis shows that mobile phone use is possibly associated with a number of deleterious effects on the spermatozoa.

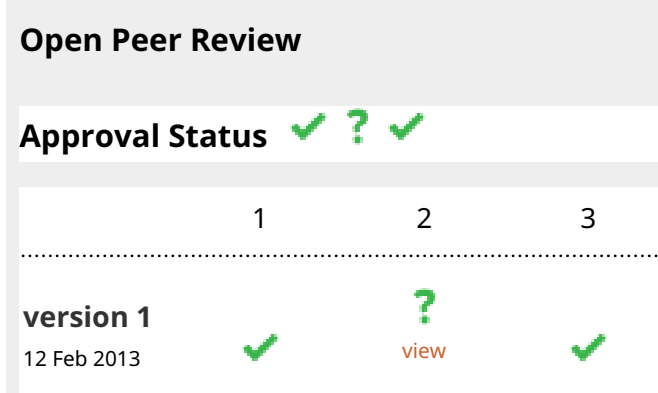

1. Nelson Bennett $(D)$, Lahey Clinic Medical

Center, Burlington, MA, USA

2. Gary Klinefelter, United States

Environmental Protection Agency, Research

Triangle Park, NC, USA

\section{Essam- Eldeen M Mohamed, Al-Azhar}

University Hospital, Assiut, Egypt

Any reports and responses or comments on the article can be found at the end of the article. 
Corresponding author: Madhukar Shivajirao Dama (madhukar262@gmail.com)

Competing interests: No competing interests were disclosed.

Grant information: The author(s) declared that no grants were involved in supporting this work.

Copyright: ( 2013 Dama MS and Bhat MN. This is an open access article distributed under the terms of the Creative Commons Attribution License, which permits unrestricted use, distribution, and reproduction in any medium, provided the original work is properly cited. Data associated with the article are available under the terms of the Creative Commons Zero "No rights reserved" data waiver (CC0 1.0 Public domain dedication).

How to cite this article: Dama MS and Bhat MN. Mobile phones affect multiple sperm quality traits: a meta-analysis [version 1; peer review: 2 approved, 1 approved with reservations] F1000Research 2013, 2:40 https://doi.org/10.12688/f1000research.2-40.v1

First published: 12 Feb 2013, 2:40 https://doi.org/10.12688/f1000research.2-40.v1 


\section{Introduction}

Almost $10 \%$ of men of reproductive age are estimated to be subfertile ${ }^{1}$. Owing to its complexity, even after identification of a plethora of underlying factors, etiology in almost half of the infertile subjects tested at fertility clinics remains obscure ${ }^{2}$. Hence, the list of the causes of male infertility is growing by the day with recent advances in fertility research ${ }^{3}$. Though advances in assisted reproduction technologies (ARTs), especially in the form of in vitro fertilization (IVF) and intracytoplasmic sperm injection (ICSI), have helped subfertile couples conceive offspring, it is feared that ARTs only bypasses the problem of subfertility and contributes towards hiding the underlying causes which have at times led to serious health problems in offspring ${ }^{4,5}$. Hence, identification of unknown aetiologies would help in prescription of specific preventive measures that will ultimately decrease the incidence of male infertility.

Most nations, especially developing countries, are witnessing an increase in the use of various radiation-emitting domestic-purpose devices that could cause mild to serious health problems based on the duration and intensity of usage ${ }^{6}$, and reduced fertility is now recognised as one such problem ${ }^{7}$. Wireless mobile phones are one of the most accepted devices with a tremendous increase in usage across the world in recent times ${ }^{8}$. Research into the impact of ionizing radiation on the development of various types of health disorders, especially cancers, has been well established ${ }^{9}$. Similarly, several studies have found an increase in the risk of developing some types of tumors after long-term exposure to non-ionizing radiation from mobile phones ${ }^{10}$. Research into the effects of mobile phone radiation on male fertility, though growing, is limited and inconclusive ${ }^{11,12}$. Recently, several case-control studies have reported results from a general population setting alongside a few studies from subfertile populations ${ }^{7,13-20}$. Like ionizing radiation, non-ionizing radiation is also expected to affect spermatozoa, though in subtle ways ${ }^{21}$. The aim of this meta-analysis was, therefore, to investigate the impact of mobile phone radia in vitro as well as in vivo settings in men of reproductive age from both general and subfertile populations.

\section{Material and methods}

A systematic search of an electronic database was conducted to retrieve published studies on the impact of mobile phone radiation on semen parameters in adult men. The results have been reported according to the standards of the guidelines for meta-analysis of observational studies in epidemiology ${ }^{22}$. All English language research studies published up until January 2012 in scientific journals indexed in the searched databases were included for analysis.

Inclusion/exclusion criteria and outcomes of interest: The studies on human males of reproductive age reporting the effect of mobile phone radiation on any or all measures of semen volume, total sperm count, sperm concentration, sperm motility or sperm morphology were included. All the studies that did not satisfy the inclusion criteria were excluded.

Search strategy, data extraction and meta-analysis: Google Scholar and NLM's PubMed database were searched for articles by using different combinations of 4 mobile phone related keywords ['mobile phone', 'cellular phone', 'radiofrequency electromagnetic waves (RF-EMW)', 'radiation'] with 5 sperm quality related keywords ('spermatozoa', 'semen', 'sperm concentration', 'sperm motility', 'sperm morphology') Data from 11 eligible studies were extracted and separated into in vitro and in vivo categories.

Effect sizes were expressed as Hedges's g $^{23}$, separately for in vivo $\&$ in vitro studies using individual semen parameters as units of analysis (Supplementary Table 1). A random model was used to test and quantify effect size using 'Comprehensive Meta-Analysis (v.2)' trial version ${ }^{24}$. A random effect model was preferred over a fixed effect model in order to account for differences in both effect size and sampling error ${ }^{25}$.

\section{Results}

In vivo effects of mobile phone radiation

Our analysis shows that overall, mobile phone users had significant deterioration in semen quality (Hedges's $g=-0.547 ; 95 \%$ CI: $-0.713,-0.382 ; p<0.001)$. There was significant heterogeneity among effect sizes $(\mathrm{Q}=475.985, \mathrm{p}<0.001)$, which suggest that some of the semen parameters may not be affected by mobile phone exposure. Hence, combined effect-size for each of the semen parameters were calculated separately (Table 1), and it was found that sperm concentration, sperm morphology, sperm motility, proportion of non-progressive motile sperm (\%), proportion of slow progressive motile sperm (\%), and sperm viability were deteriorated in individuals exposed to mobile phone radiation. By contrast, semen volume, liquefaction time, semen $\mathrm{pH}$, proportion of rapid progressive motile sperm (\%), and semen viscosity were not affected by mobile phone usage.

Publication bias could potentially change the results of metaanalysis but analysis of funnel plot of precision by Hedges's $g$ using Dual and Tweedie's trim-and-fill test ${ }^{26}$ did not change the overall effect size, suggesting little bias. Moreover, Rosenthal's fail-safe $\mathrm{N}$ test ${ }^{27}$ revealed that 3964 missing studies with a mean Hedges's $g$ of 0 are required for the combined 2-tailed p-value to exceed 0.050 . In other words, there need to be 99.1 missing studies for every observed study for the effect to be nullified.

\section{In vitro effects of mobile phone radiation}

Experimental exposure of spermatozoa isolated from healthy men of reproductive age to mobile phone radiation significantly affected sperm quality (Hedges's $g=-2.233 ; 95 \%$ CI: $-2.758,-1.708$; $p<0.001)$. There was significant heterogeneity among effect sizes $(\mathrm{Q}=639.294, \mathrm{p}<0.001)$, suggesting that similar to in vivo exposure, in vitro exposure may also not affect all the parameters of spermatozoa. Hence, combined effect-size for spermatozoa parameters were calculated separately (Table 1), and it was found that exposure to mobile phones significantly reduced straight line velocity, fast progressive motility, Hypo-osmotic swelling (HOS) test score, major axis $(\mu \mathrm{m})$, minor axis $(\mu \mathrm{m})$, total sperm motility, perimeter $(\mu \mathrm{m})$, area $\left(\mu \mathrm{m}^{2}\right)$, average path velocity, curvilinear velocity, motile spermatozoa, and acrosome reacted spermatozoa (\%). By contrast, DNA fragmentation levels, non-progressive motility, total antioxidant capacity (TAC), progressive motility, reactive oxygen species (ROS) generation, slow progressive motility, sperm concentration, and sperm zona binding was not affected by mobile phone radiation. 
Table 1. Effect sizes of mobile phone radiation on sperm quality traits.

\begin{tabular}{|c|c|c|c|}
\hline & Sample size & Hedges's g & $p$-value \\
\hline \multicolumn{4}{|c|}{ In vivo studies } \\
\hline Semen volume & 591 & 0.09774 & 0.29458 \\
\hline Sperm concentration & 874 & -0.66388 & 0.01858 \\
\hline Sperm morphology & 746 & -1.28325 & 0.00000 \\
\hline Sperm motility & 1079 & -0.81584 & 0.00102 \\
\hline Proportion of non-progressive motile sperm (\%) & 283 & -0.16136 & 0.03396 \\
\hline Proportion of rapid progressive motile sperm (\%) & 283 & -0.25708 & 0.09969 \\
\hline Proportion of slow progressive motile sperm (\%) & 283 & -0.39031 & 0.00765 \\
\hline Liquefaction time (min) & 321 & -0.11449 & 0.28277 \\
\hline $\mathrm{pH}$ & 321 & -0.36681 & 0.05592 \\
\hline Sperm viability (\%) & 321 & -1.13150 & 0.00220 \\
\hline Semen viscosity & 321 & -0.00924 & 0.93083 \\
\hline \multicolumn{4}{|c|}{ In vitro studies } \\
\hline Acrosome reaction (\%) & 24 & -1.69939 & 0.00000 \\
\hline Sperm area $\left(\mu m^{2}\right)$ & 24 & -6.79952 & 0.00004 \\
\hline Average path velocity & 20 & -8.16777 & 0.00000 \\
\hline Curvilinear velocity & 20 & -10.37987 & 0.00000 \\
\hline DNA fragmentation & 32 & 0.10182 & 0.68034 \\
\hline Fast progressive motility & 49 & -0.50794 & 0.01195 \\
\hline Hypo-osmotic swelling (HOS) & 20 & 1.721867 & 0.000002 \\
\hline Major axis $(\mu \mathrm{m})$ & 24 & -3.62708 & 0.01918 \\
\hline Minor axis $(\mu m)$ & 24 & -7.4825 & 0.0361 \\
\hline Sperm motility & 105 & -2.82739 & 0.00118 \\
\hline Non motile spermatozoa & 49 & -0.61615 & 0.03275 \\
\hline Non progressive motility & 49 & 0.04371 & 0.82612 \\
\hline Perimeter $(\mu \mathrm{m})$ & 24 & -5.53132 & 0.01897 \\
\hline Progressive motility & 12 & -0.04606 & 0.90700 \\
\hline Reactive oxygen species (ROS) & 36 & -11.37087 & 0.33592 \\
\hline Slow progressive motility & 49 & -0.14543 & 0.67535 \\
\hline Sperm concentration & 59 & -0.02309 & 0.89887 \\
\hline Sperm zona binding & 10 & -0.68402 & 0.12153 \\
\hline Straight line velocity & 20 & -6.37614 & 0.00000 \\
\hline Total antioxidant capacity (TAC) & 32 & -0.25102 & 0.31138 \\
\hline Viability (\%) & 56 & -2.75116 & 0.02543 \\
\hline
\end{tabular}

A Funnel plot of precision by Hedges's g using Dual and Tweedie's trim-and-fill test did not change the overall effect size, suggesting little publication bias. Rosenthal's fail-safe $\mathrm{N}$ test revealed that 3813 missing studies with a mean Hedges's $g$ of 0 are required for the combined 2-tailed p-value to exceed 0.050. In other words, there need to be 100.3 missing studies for every observed study for the effect to be nullified.

\section{Discussion}

This study was aimed to analyse the data assessing the risk of mobile phone radiation on male fertility. Our results suggest that mobile phone radiation has a tendency to significantly affect sperm quality. Based on the design of the analysed records, we divided studies into in vivo studies and in vitro studies. The effect size was significant in both the categories, suggesting that mobile phone radiation could severely compromise male fertility. This conclusion is robust, as a fail-safe test suggested that the results are not likely to be mediated by publication bias.

The number of worldwide mobile subscriptions grew from less than 1 billion in 2000 to over 6 billion in $2012^{8}$, with more than half of these subscribers estimated to be children and young adults. Hence, it is very likely that in the coming decades, we could witness an increase in the incidence of male infertility due to mobile phone radiation exposure, similar to growing concerns over other hazards. Although the mechanism of cell phone radiation-mediated health defects is still obscure, it is proposed that their ability to produce heat, disrupt cell membranes, affect endothelial function, alter the blood-brain barrier, and modulate neuronal excitability have the potential to affect multiple physiological functions simultaneously ${ }^{28-30}$. 
To our knowledge, this is the first meta-analysis of the effects of mobile phone radiations on various sperm quality parameters. Cellular phones have become integral part of everyday life, and newer versions of these are developed very rapidly these days. Hence, it is necessary to educate the users about the hazards of cell phones as well as test the newer versions like smartphones for health hazards.

\section{Competing interests}

No relevant competing interests were disclosed.

Grant information

The author(s) declared that no grants were involved in supporting this work.

\section{Supplementary table}

Supplementary Table 1. Effect sizes of sperm quality traits from the studies included in the analysis.

\begin{tabular}{|c|c|c|c|c|}
\hline Reference & Subgroup & Outcome & $\begin{array}{l}\text { Effect size } \\
\text { (Hedges's g) }\end{array}$ & $p$-value \\
\hline \multicolumn{5}{|c|}{ In vivo studies } \\
\hline \multirow{10}{*}{ [7] } & \multirow{5}{*}{1} & Proportion of non-progressive motile sperm (\%) & -0.11444 & 0.19545 \\
\hline & & Proportion of rapid progressive motile sperm (\%) & -0.39434 & 0.00001 \\
\hline & & Proportion of slow progressive motile sperm (\%) & -0.51671 & 0.00000 \\
\hline & & Sperm concentration & 0.01922 & 0.82778 \\
\hline & & Sperm motility & -0.14692 & 0.09667 \\
\hline & \multirow{5}{*}{2} & Proportion of non-progressive motile sperm (\%) & -0.28478 & 0.04855 \\
\hline & & Proportion of rapid progressive motile sperm (\%) & -0.07945 & 0.58037 \\
\hline & & Proportion of slow progressive motile sperm (\%) & -0.22090 & 0.12525 \\
\hline & & Sperm concentration & -0.12467 & 0.38594 \\
\hline & & Sperm motility & 0.00940 & 0.94784 \\
\hline \multirow{2}{*}{ [13] } & \multirow{2}{*}{1} & Sperm morphology & -0.74105 & 0.00000 \\
\hline & & Sperm motility & -0.57347 & 0.00000 \\
\hline \multirow{24}{*}{ [14] } & \multirow{8}{*}{1} & Liquefaction time (min) & -0.01209 & 0.94773 \\
\hline & & $\mathrm{pH}$ & 0.00000 & 1.00000 \\
\hline & & Semen volume & 0.18269 & 0.32253 \\
\hline & & Sperm concentration & -0.42958 & 0.02095 \\
\hline & & Sperm morphology & -0.72462 & 0.00013 \\
\hline & & Sperm motility & -0.40596 & 0.02896 \\
\hline & & Viability & -0.43282 & 0.02002 \\
\hline & & Viscosity & 0.01942 & 0.91612 \\
\hline & \multirow{8}{*}{2} & Liquefaction time (min) & -0.23709 & 0.20389 \\
\hline & & $\mathrm{pH}$ & -0.46407 & 0.01363 \\
\hline & & Semen volume & -0.02014 & 0.91380 \\
\hline & & Sperm concentration & -0.56141 & 0.00298 \\
\hline & & Sperm morphology & -1.70950 & 0.00000 \\
\hline & & Sperm motility & -1.32047 & 0.00000 \\
\hline & & Viability & -1.34677 & 0.00000 \\
\hline & & Viscosity & -0.09456 & 0.61148 \\
\hline & \multirow{8}{*}{3} & Liquefaction time (min) & -0.09749 & 0.59412 \\
\hline & & $\mathrm{pH}$ & -0.63951 & 0.00060 \\
\hline & & Semen volume & 0.28711 & 0.11786 \\
\hline & & Sperm concentration & -0.87694 & 0.00000 \\
\hline & & Sperm morphology & -1.95983 & 0.00000 \\
\hline & & Sperm motility & -1.58904 & 0.00000 \\
\hline & & Viability & -1.62719 & 0.00000 \\
\hline & & Viscosity & 0.04490 & 0.80606 \\
\hline \multirow{5}{*}{ [15] } & \multirow{5}{*}{1} & Semen volume & -0.07567 & 0.69348 \\
\hline & & Sperm concentration & -2.09426 & 0.00000 \\
\hline & & Sperm morphology & -1.35171 & 0.00000 \\
\hline & & Sperm motility & -1.80265 & 0.00000 \\
\hline & & Overall effect & -0.54948 & 0.00000 \\
\hline
\end{tabular}




\begin{tabular}{|c|c|c|c|c|}
\hline Reference & Subgroup & Outcome & $\begin{array}{l}\text { Effect size } \\
\text { (Hedges's g) }\end{array}$ & $p$-value \\
\hline \multicolumn{5}{|c|}{ In vivo studies } \\
\hline \multirow{6}{*}{ [16] } & \multirow{6}{*}{1} & Fast progressive motility & -0.48612 & 0.07419 \\
\hline & & Motility & -0.73467 & 0.00808 \\
\hline & & Non motile & -0.89668 & 0.00146 \\
\hline & & Non progressive motility & 0.14043 & 0.60105 \\
\hline & & Slow progressive motility & -0.48268 & 0.07620 \\
\hline & & Sperm concentration & -0.05135 & 0.84822 \\
\hline \multirow{6}{*}{ [20] } & \multirow{6}{*}{1} & Dna fragmentation & 0.10182 & 0.68034 \\
\hline & & Motility & -0.19307 & 0.43544 \\
\hline & & ROS & -0.29465 & 0.23542 \\
\hline & & Sperm concentration & 0.00085 & 0.99725 \\
\hline & & TAC & -0.25102 & 0.31138 \\
\hline & & Viability (\%) & -0.46743 & 0.06193 \\
\hline \multirow[t]{2}{*}{ [17] } & 1 & Progressive motility & -0.04606 & 0.90700 \\
\hline & \multirow{3}{*}{1} & Motility & -16.10595 & 0.00008 \\
\hline \multirow[t]{2}{*}{ [31] } & & ROS & -23.97770 & 0.00007 \\
\hline & & Viability (\%) & -11.52174 & 0.00009 \\
\hline \multirow{11}{*}{ [32] } & \multirow{6}{*}{1} & Acrosome (\%) & -1.58348 & 0.00051 \\
\hline & & Area $\left(\mu m^{2}\right)$ & -8.61098 & 0.00000 \\
\hline & & Major axis $(\mu \mathrm{m})$ & -5.25493 & 0.00000 \\
\hline & & Minor axis $(\mu \mathrm{m})$ & -11.21546 & 0.00000 \\
\hline & & Perimeter $(\mu \mathrm{m})$ & -8.00952 & 0.00000 \\
\hline & & Sperm zona binding & -0.68402 & 0.12153 \\
\hline & \multirow{5}{*}{2} & Acrosome (\%) & -1.82487 & 0.00012 \\
\hline & & Area $\left(\mu m^{2}\right)$ & -5.27741 & 0.00000 \\
\hline & & Major axis $(\mu \mathrm{m})$ & -2.15357 & 0.00002 \\
\hline & & Minor axis $(\mu \mathrm{m})$ & -4.06799 & 0.00000 \\
\hline & & Perimeter $(\mu \mathrm{m})$ & -3.28849 & 0.00000 \\
\hline \multirow{5}{*}{ [18] } & \multirow{5}{*}{1} & Fast progressive motility & -0.53471 & 0.07618 \\
\hline & & Motility & -0.64188 & 0.03467 \\
\hline & & Non motile & -0.31928 & 0.28406 \\
\hline & & Non progressive motility & -0.07395 & 0.80286 \\
\hline & & Slow progressive motility & 0.21209 & 0.47510 \\
\hline \multirow{7}{*}{ [19] } & \multirow{7}{*}{1} & Average path velocity & -8.16777 & 0.00000 \\
\hline & & Curvilinear velocity & -10.37987 & 0.00000 \\
\hline & & HOS & 1.72187 & 0.00000 \\
\hline & & Motility & -9.78102 & 0.00000 \\
\hline & & Straight line velocity & -6.37614 & 0.00000 \\
\hline & & Viability (\%) & -2.53934 & 0.00000 \\
\hline & & Overall effect size & -2.23292 & 0.00000 \\
\hline
\end{tabular}

1. de Kretser DM: Male infertility. Lancet. 1997; 349(9054): 787-90. PubMed Abstract | Publisher Full Text

2. Matzuk MM, Lamb DJ: The biology of infertility: research advances and clinica challenges. Nat Med. 2008; 14(11): 1197-213.

PubMed Abstract | Publisher Full Text

3. Kilgallon SJ, Simmons LW: Image content influences men's semen quality. Biol Lett. 2005; 1(3): 253-5.

PubMed Abstract | Publisher Full Text | Free Full Text

4. Davies MJ, Moore VM, Willson KJ, et al:: Reproductive technologies and the risk of birth defects. N Engl J Med. 2012; 366(19): 1803-13.

PubMed Abstract | Publisher Full Text

5. Wen J, Jiang J, Ding C, et al:: Birth defects in children conceived by in vitro fertilization and intracytoplasmic sperm injection: a meta-analysis. Fertil Steril. 2012; 97(6): 1331-7.e1-4

PubMed Abstract | Publisher Full Text
6. Sage C, Carpenter D: Biolnitiative Working G: Biolnitiative report : a rationale for a biologically-based public exposure standard for electromagnetic fields (ELF and RF). [United States]: Biolnitiative Working Group, 2007. Reference Source

7. Fejes I, Závaczki Z, Szöllosi J, et al:: Is there a relationship between cell phone use and semen quality? Arch Androl. 2005; 51(5): 385-93.

PubMed Abstract | Publisher Full Text

8. World Bank. Information and Communication T, infoDev, World B. Maximizing mobile : 2012 information and communications for development. In. Washington, D.C.: World Bank: InfoDev. Reference Source

9. Ahlbom A, Green A, Kheifets L, et al:: Epidemiology of health effects of radiofrequency exposure. Environ Health Perspect. 2004; 112(17): 1741-54. PubMed Abstract | Publisher Full Text | Free Full Text 
10. Myung SK, Ju W, McDonnell DD, et al.: Mobile phone use and risk of tumors: a meta-analysis. J Clin Oncol. 2009; 27(33): 5565-72. PubMed Abstract | Publisher Full Text

11. Agarwal A, Singh A, Hamada A, et al.: Cell phones and male infertility: a review of recent innovations in technology and consequences. Int Braz J Urol. 2011; 37(4): 432-54 PubMed Abstract

12. Merhi ZO: Challenging cell phone impact on reproduction: a review. $J$ Assist Reprod Genet. 2012; 29(4): 293-7. PubMed Abstract | Publisher Full Text | Free Full Text

13. Wdowiak $\mathrm{A}$, Wdowiak $\mathrm{L}$, Wiktor $\mathrm{H}$ : Evaluation of the effect of using mobile phones on male fertility. Ann Agric Environ Med. 2007; 14(1): 169-72. PubMed Abstract

14. Agarwal A, Deepinder F, Sharma RK, et al.: Effect of cell phone usage on semen analysis in men attending infertility clinic: an observational study. Fertil Steril. 2008; 89(1): 124-8.

PubMed Abstract | Publisher Full Text

15. Sajeda S, Al-Wattar YT: Effect of mobile phone usage on semen analysis in infertile men. Tikrit J Pharm Sci. 2011; 7(1): 77-82.

16. Erogul $\mathrm{O}, \mathrm{Oztas} \mathrm{E}$, Yildirim I, et al.: Effects of electromagnetic radiation from a cellular phone on human sperm motility: an in vitro study. Arch Med Res. 2006; 37(7): 840-3.

PubMed Abstract | Publisher Full Text

17. Falzone $\mathrm{N}$, Huyser $\mathrm{C}$, Fourie $\mathrm{F}$, et al.: In vitro effect of pulsed $900 \mathrm{MHz}$ GSM radiation on mitochondrial membrane potential and motility of human spermatozoa. Bioelectromagnetics. 2008; 29(4): 268-76. PubMed Abstract | Publisher Full Text

18. Ahmad L, Baig NM: Mobile Phone RF-EMW Exposure to Human Spermatozoa: An in vitro Study. Pakistan J Zool. 2011; 43(6): 1147-54. Reference Source

19. Dkhil MA, Danfour MA, Al-Quraishy S: Sperm function is affected by the electromagnetic radiation emitted by mobile phone. Afr J Microbiol Res. 2011; 5(27): 4896-900.

Publisher Full Text

20. Agarwal A, Desai NR, Makker K, et al.: Effects of radiofrequency electromagnetic waves (RF-EMW) from cellular phones on human ejaculated semen: an in vitro pilot study. Fertil Steril. 2009; 92(4): 1318-25. PubMed Abstract | Publisher Full Text

21. Dasdag S, Ketani MA, Akdag Z, et al:: Whole-body microwave exposure emitted by cellular phones and testicular function of rats. Urol Res. 1999 27(3): 219-23.

PubMed Abstract

22. Stroup DF, Berlin JA, Morton SC, et al:: Meta-analysis of observational studies in epidemiology: a proposal for reporting. Meta-analysis Of Observational Studies in Epidemiology (MOOSE) group. JAMA. 2000; 283(15): 2008-12. PubMed Abstract | Publisher Full Text

23. Hedges LV, Olkin I: Statistical methods for meta-analysis. Orlando: Academic Press, 1985. Reference Source

24. Borenstein $\mathrm{M}$, Hedges $\mathrm{L}$, Higgins $\mathrm{J}$, et al:: Comprehensive meta-analysis (Version 2) [Computer software]. Englewood, NJ BioStat, 2005.

25. Sutton AJ: Methods for meta-analysis in medical research. Chichester; New York: J. Wiley, 2000.

Reference Source

26. Duval S, Tweedie R: A Nonparametric "Trim and Fill" Method of Accounting for Publication Bias in Meta-Analysis. J Am Statistical Assoc. 2000; 95(449): 89-98. Publisher Full Text

27. Orwin RG: A Fail-Safe $\mathbf{N}$ for Effect Size in Meta-Analysis. J Educational Statistics 1983; 8(2): 157-59.

Publisher Full Text

28. Straume A, Oftedal G, Johnsson A: Skin temperature increase caused by a mobile phone: a methodological infrared camera study. Bioelectromagnetics. 2005; 26(6): 510-9.

PubMed Abstract | Publisher Full Text

29. Behari J: Biological responses of mobile phone frequency exposure. Indian $J$ Exp Biol. 2010; 48(10): 959-81. PubMed Abstract

30. Juutilainen J, de Seze R: Biological effects of amplitude-modulated radiofrequency radiation. Scand J Work Environ Health. 1998; 24(4): 245-54. PubMed Abstract | Publisher Full Text

31. De luliis GN, Newey RJ, King BV, et al.: Mobile phone radiation induces reactive oxygen species production and DNA damage in human spermatozoa in vitro. PloS one. 2009; 4(7): e6446.

PubMed Abstract | Publisher Full Text | Free Full Text

32. Falzone $\mathrm{N}$, Huyser $\mathrm{C}$, Becker $\mathrm{P}$, et al:: The effect of pulsed $900-\mathrm{MHz}$ GSM mobile phone radiation on the acrosome reaction, head morphometry and zona binding of human spermatozoa. Int J Androl. 2011; 34(1): 20-26. PubMed Abstract | Publisher Full Text 


\section{Open Peer Review}

\section{Current Peer Review Status:}

\section{Version 1}

Reviewer Report 25 March 2013

https://doi.org/10.5256/f1000research.862.r861

(C) 2013 Mohamed E. This is an open access peer review report distributed under the terms of the Creative Commons Attribution License, which permits unrestricted use, distribution, and reproduction in any medium, provided the original work is properly cited.

Essam- Eldeen M Mohamed

Department of Dermatology and Andrology, Al-Azhar University Hospital, Assiut, Egypt

Competing Interests: No competing interests were disclosed.

I confirm that I have read this submission and believe that I have an appropriate level of expertise to confirm that it is of an acceptable scientific standard.

Reviewer Report 14 March 2013

https://doi.org/10.5256/f1000research.862.r808

(C) 2013 Klinefelter G. This is an open access peer review report distributed under the terms of the Creative Commons Attribution License, which permits unrestricted use, distribution, and reproduction in any medium, provided the original work is properly cited.

\section{Gary Klinefelter}

Gamete and Early Embryo Biology Branch, Reproductive Toxicology Division, United States Environmental Protection Agency, Research Triangle Park, NC, USA

On the surface, the results seem quite striking with virtually any sperm endpoint one can imagine being significantly altered in the collective analysis of mobile phone studies compiled. However, upon looking at the data in the supplementary table, it is obvious that the relatively few studies compiled varied widely both in respect to endpoints measured and the sample size. As shown in Table 1, motility is the endpoint representing the greatest combined sample size for both in vivo and in vitro studies. Motility was measured in 4 out of 4 in vivo studies and 5 out of 7 in vitro studies. So motility 'might' be an endpoint that is repeatedly altered by cell phone exposure. The reason for 'might' is the lack of any reported exposure data in this study.

In summary, the small sample size and lack of exposure data significantly weaken the conclusions 
of this study.

Competing Interests: No competing interests were disclosed.

I confirm that I have read this submission and believe that I have an appropriate level of expertise to confirm that it is of an acceptable scientific standard, however I have significant reservations, as outlined above.

Author Response 02 Apr 2013

Madhukar Dama, Institute of Wildlife Veterinary Research, Kodagu District, Karnataka, India

We have studied the reviewer comments and would like to justify our results. Our analysis is showing that mobile phone radiations could affect many sperm parameters. This could be due to interdependence of sperm parameters (Acta Eur Fertil. 1982;13(2):49-54). We also agree with the point that the number of studies is few and total sample size in in vitro studies is smaller. However, it must be noted that the sample size is weighted during metaanalysis, which nullifies the problems posed by smaller sample size studies. Apart from motility, other parameters like morphology, concentration, and viability are also significantly affected by in vivo exposure. Hence we have provided all the effect sizes individually along with $\mathrm{p}$ values and sample size. We hope that our points justify the reviewer comments.

Competing Interests: None

Reviewer Report 19 February 2013

https://doi.org/10.5256/f1000research.862.r780

(c) 2013 Bennett N. This is an open access peer review report distributed under the terms of the Creative Commons Attribution License, which permits unrestricted use, distribution, and reproduction in any medium, provided the original work is properly cited.

\section{Nelson Bennett}

Institute of Urology, Lahey Clinic Medical Center, Burlington, MA, USA

Competing Interests: No competing interests were disclosed.

I confirm that I have read this submission and believe that I have an appropriate level of expertise to confirm that it is of an acceptable scientific standard. 
The benefits of publishing with F1000Research:

- Your article is published within days, with no editorial bias

- You can publish traditional articles, null/negative results, case reports, data notes and more

- The peer review process is transparent and collaborative

- Your article is indexed in PubMed after passing peer review

- Dedicated customer support at every stage

For pre-submission enquiries, contact research@f1000.com 